PACS: $61.10-\mathrm{i} ; 81.20 .-\mathrm{n}$

\title{
CLINOPTILOLITE WITH CESIUM IMMOBILIZATION TO POTASSIUM MAGNESIUM PHOSPHATE MATRIX
}

\author{
S.Yu. Sayenko, V.A. Shkuropatenko, N.P. Dikiy, R.V. Tarasov, K.A. Ulybkina, \\ O.Y. Surkov, L.M. Litvinenko \\ National Science Center "Kharkov Institute of Physics and Technology» \\ 1, Academicheskaya st., Kharkov 61108, Ukraine \\ e-mail:prudyvusk@kipt.kharkov.ua \\ Received March 3, 2017
}

\begin{abstract}
The possibility of potassium magnesium phosphate (PMP) matrix application for immobilization of clinoptilolite with simulator of radioactive cesium isotopes was investigated. $\mathrm{X}$-ray phase analysis of the natural clinoptilolite sample has shown that it includes two main phases of clinoptilolite $(\mathrm{Na}, \mathrm{K})_{4} \mathrm{CaAl}_{6} \mathrm{Si}_{30} \mathrm{O}_{72} \cdot 24 \mathrm{H}_{2} \mathrm{O}$, and mordenite $\left(\mathrm{Na}_{2} \mathrm{Ca}, \mathrm{K}_{2}\right){ }_{4} \mathrm{Al}_{8} \mathrm{Si}_{40} \mathrm{O}_{96} \cdot 28 \mathrm{H}_{2} \mathrm{O}$. In addition, impurities of $\mathrm{SiO}_{2}, \mathrm{Fe}_{2} \mathrm{O}_{3}$ and $\mathrm{TiO}_{2}$ phases are observed. To saturate clinoptilolite with cesium, $0.5 \mathrm{M}$ solution of cesium chloride was used. A chemical analysis of clinoptilolite after saturation with cesium has demonstrated that the content of cesium in clinoptilolite was about 2 wt.\%. After the introduction of clinoptilolite with cesium in the PMP matrix, the obtained material was identified as potassiummagnesium phosphate with the presence of clinoptilolite, mordenite, $\mathrm{TiO}_{2}$ and unreacted $\mathrm{MgO}$ phases. The results of the electron microscopy analysis have shown that cesium was dislocated between PMP matrix and clinoptilolite, incorporated into the PMP matrix. Normalized leaching rate of cesium from PMP matrix with $25 \mathrm{wt} . \%$ clinoptilolite was about $3.2 .10^{-4} \mathrm{~g} / \mathrm{cm}^{2}$ per day after 7 days testing.
\end{abstract}

KEY WORDS: clinoptilolite, potassium magnesium phosphate matrix, cesium chloride, X-ray analysis, corrosion resistance.

ІММОБІЛІЗАЦІЯ КЛИНОПТИЛОЛІТУ 3 ЦЕЗІЕМ У КАЛІЙ-МАГНІЙ ФОСФАТНУ МАТРИЦЮ

С.Ю. Саєнко, В.А. Шкуропатенко, М.П. Дикий, Р.В. Тарасов, К.А. Улибкіна, О.С. Сурков, Л.М. Литвиненко Національний науковий центр «Харківський фізико-технічний інститут» вул. Академічна 1, Харків, Украӥна, 61108

Досліджено можливість використання калій - магній фосфатної матриці (КМФ) для іммобілізації клиноптилоліта, що містить імітатор радіоактивних ізотопів цезію. Рентгенофазовий аналіз зразка природного клиноптилоліта показав, що в його склад входить дві основні фази клиноптилоліт $(\mathrm{Na}, \mathrm{K})_{4} \mathrm{CaAl}_{6} \mathrm{Si}_{30} \mathrm{O}_{72} \cdot 24 \mathrm{H}_{2} \mathrm{O}$ і морденіт $\left(\mathrm{Na}_{2} \mathrm{Ca}_{2} \mathrm{~K}_{2}\right){ }_{4} \mathrm{Al}_{8} \mathrm{Si}_{40} \mathrm{O}_{96} \cdot 28 \mathrm{H}_{2} \mathrm{O}$, a також спостерігаються домішки фаз $\mathrm{SiO}_{2}, \mathrm{Fe}_{2} \mathrm{O}_{3} \mathrm{i} \mathrm{TiO}$. Для насичення клиноптилоліта цезієм використовували $0,5 \mathrm{M}$ розчин хлориду цезію. Проведений хімічний аналіз клиноптилоліта після насичення цезієм показав, що вміст цезію в клиноптилоліті становить 12 мас.\%. Після введення клиноптилоліта з цезієм в КМФ матрицю отриманий матеріал ідентифікується як калій-магнієвий фосфат з присутністю фаз клиноптилоліта, морденіта, $\mathrm{TiO}_{2}$ i $\mathrm{MgO}$, який не прореагував. Результати електронно-мікроскопічних досліджень показали, що цезій розподілився між КМФ матрицею $\mathrm{i}$ клиноптилолітом, який інкорпорований в КМФ матрицю. Нормалізована швидкість вилуговування цезію із зразків КМФ матриці з 25 ваг.\% клиноптилоліта становить $3,2 \cdot 10^{-4}$ г / см².доб. на 7-у добу випробувань.

КЛЮЧОВІ СЛОВА: клиноптилоліт, калій - магній фосфатна матриця, хлорид цезію, рентгенофазовий аналіз, корозійна стійкість.

ИММОБИЛИЗАЦИЯ КЛИНОПТИЛОЛИТА С ЦЕЗИЕМ В КАЛИЙ-МАГНИЙ ФОСФАТНУЮ МАТРИЦУ

С.Ю. Саенко, В.А. Шкуропатенко, Н.П. Дикий, Р.В. Тарасов, Е.А. Улыбкина, А.Е. Сурков, Л.М. Литвиненко Национальный Научный Центр «Харьковский физико-технический институт»

ул. Академическая 1, Харьков, Украина, 61108

Исследована возможность использования калий- магний фосфатной матрицы (КМФ) для иммобилизации клиноптилолита, содержащего имитатор радиоактивных изотопов цезия. Рентгенофазовый анализ образца природного клиноптилолита показал, что в его состав входит две основные фазы клиноптилолит $(\mathrm{Na}, \mathrm{K})_{4} \mathrm{CaAl}_{6} \mathrm{Si}_{30} \mathrm{O}_{72} \cdot 24 \mathrm{H}_{2} \mathrm{O}$ и морденит $\left(\mathrm{Na}_{2} \mathrm{Ca}, \mathrm{K}_{2}\right)_{4} \mathrm{Al}_{8} \mathrm{Si}_{40} \mathrm{O}_{96} \cdot 28 \mathrm{H}_{2} \mathrm{O}$, а также наблюдаются примеси фаз $\mathrm{SiO}_{2}, \mathrm{Fe}_{2} \mathrm{O}_{3}$ и $\mathrm{TiO}_{2}$. Для насыщения клиноптилолита цезием использовали $0,5 \mathrm{M}$ раствор хлорида цезия. Проведенный химический анализ клиноптилолита после насыщения цезием показал, что содержание цезия в клиноптилолите составляет $\sim 12$ вес.\%. После введения клиноптилолита с цезием в КМФ матрицу полученный материал идентифицируется как калий-магниевый фосфат с присутствием фаз клиноптилолита, морденита, $\mathrm{TiO}_{2}$ и не прореагировавшего $\mathrm{MgO}$. Результаты электронно-микроскопических исследований показали, что цезий распределился между КМФ матрицей и клиноптилолитом, который инкорпорирован в КМФ матрицу. Нормализованная скорость выщелачивания цезия из образцов КМФ матрицы с 25 вес.\% клиноптилолита составляет $3,2 \cdot 10^{-4}$ г/см². сутки на 7-ые сутки испытаний.

КЛЮЧЕВЫЕ СЛОВА: клиноптилолит, калий - магний фосфатная матрица, хлорид цезия, рентгенофазовый анализ, коррозионная стойкость.

Одним из основных методов извлечения радионуклидов из жидких радиоактивных отходов, которые образуются в результате работы АЭС, является сорбционный метод. В качестве неорганических сорбентов, наряду с другими, используют природные и синтетические цеолиты. Цеолиты представляют собой алюмосиликаты, в которых каждый атом Si и Al окружен четырьмя атомами кислорода, образуя тетраэдры, 
соединяющиеся друг с другом вершинами и формирующие упорядоченную структуру с полостями и каналами. Природные цеолиты значительно дешевле, чем синтетические и обладают достаточно высокой ионообменной емкостью и механической прочностью.

Природные цеолиты широко применяются в атомной энергетике в качестве сорбентов для очистки вод бассейнов-охладителей отработанного ядерного топлива, дезактивации оборудования ядерных объектов. При ликвидации последствий аварии на ЧАЭС использовались цеолиты [1].

В настоящее время известно более 40 структурных видов природных цеолитов, наиболее распространенными из которых являются клиноптилолит, гейландит, морденит, шабазит, анальцим и др. Клиноптилолит занимает особое место среди природных цеолитов, благодаря его высокой радиационной и термической стойкости. Клиноптилолит является высокоселективным сорбентом по отношению к крупным ионам, что делает его предпочтительным при использовании в качестве сорбента радиоактивных изотопов щелочных и щелочноземельных элементов с большим ионным радиусом [2].

Ионообменный характер сорбции накладывает свою специфику на свойства различных сорбентов, в том числе и клиноптилолита. Обратимость ионообменной реакции приводит к созданию условий для вымывания радионуклидов при хранении отработанных сорбентов [3]. Поэтому для надежной изоляции отработанных сорбентов необходимо обеспечить их включение в матричный материал, что будет гарантировать локализацию радионуклидов в процессе хранения и дальнейшего захоронения.

В работе J.M. Juoi, M.I. Ojovan, W.E. Lee [4] проведены исследования возможности использования боросиликатного стекла для иммобилизации клиноптилолита, содержащего цезий. Создание матрицы из боросиликатного стекла достигалось смешиванием порошков боросиликатного стекла и цезийсодержащего клиноптилолита в разных объемных отношениях от 1:1 до 1:10 (от 37 до 88 вес.\%) с последующим формованием таблеток и их спеканием при $750{ }^{\circ} \mathrm{C}, 2$ часа. Низкая скорость выщелачивания цезия сохраняется при загрузке клиноптилолитом до $73 \%$ вес. Однако при этом необходимо учитывать, что процесс остекловывания является энергоемким и дорогостоящим процессом при реализации в больших масштабах. Кроме того, остекловывание подразумевает использование высоких температур, при которых происходит деструкция структуры клиноптилолита, и повышается вероятность улетучивания цезия. Поэтому, существует необходимость в получении матриц для иммобилизации отработанных сорбентов при низких температурах.

$\mathrm{B}$ настоящее время калий-магний фосфатная керамика $\mathrm{KMgPO}_{4} \quad 6 \mathrm{H}_{2} \mathrm{O}$ предложен для иммобилизации твердых радиоактивных отходов, жидких радиоактивных отходов и шламов [5-8]. Калий-магний фосфатную керамику, которая имеет комнатную температуру синтеза и высокие коррозионные и радиационные свойства, по-видимому, целесообразно использовать для иммобилизации отработанных сорбентов.

Целью данной работы являлось исследование возможности использования калий- магний фосфатной матрицы для иммобилизации клиноптилолита, содержащего имитатор радиоактивных изотопов цезия.

\section{МАТЕРИАЛЫ И МЕТОДЫ}

Для синтеза калий-магниевого фосфата (КМФ) использовали следующие реактивы: оксид магния МgO (марка ч.), термообработанный при температуре $1300{ }^{\circ} \mathrm{C}$ в течение 1 часа, дигидрофосфат калия $\mathrm{KH}_{2} \mathrm{PO}_{4}($ марка ч.), дистиллированная вода ( $\mathrm{HH}=5,5)$. Исследование возможностей КМФ матрицы для кондиционирования отработанных сорбентов проводили с использованием природного клиноптилолита (Сокирницкое месторождение). Термообработку КМФ образцов осуществляли на воздухе в высокотемпературной электропечи Nabertherm P310 (Германия). Для измельчения порошков использовали планетарную мономельницу «Рulverisette 6» (Германия). Фазовый состав материалов до и после термообработок исследовали методом рентгеноструктурного анализа (ДРОН - 1,5, $\mathrm{Cu} \mathrm{K}_{\alpha}$ с никелевым фильтром для ослабления К составляющей характеристического излучения). Для идентификации фаз использовалась база дифракционных данных ASTM. Для определения процессов, проходивших при нагревании КМФ порошков, проводили дифференциально -термический анализ (ДТА) на термоанализаторе SDT Q600 V20.9 Build 20 (США) в интервале температур 20-1000 ${ }^{\circ} \mathrm{C}$, скорость нагрева $10{ }^{\circ} \mathrm{C} /$ мин. Исследование микроструктуры образцов проводили на растровом (сканирующем) электронном микроскопе JSM-7001F (JEOL, Япония) оборудованном термополевой электронной пушкой. Анализ состава образцов проведен методом энергодисперсионного рентгеновского микроанализа при помощи анализатора INCA Penta FETx3 (Oxford Instruments, Великобритания). Элементный анализ твердых образцов определяли с помощью лазерного масс-спектрометра высокого разрешения ЭМАЛ-2 с двойной фокусировкой. Методом атомно-абсорбционной спектрометрии (спектрометр Ace 3000 фирмы Thermo Scientific) определяли концентрацию цезия в выщелате.

\section{РЕЗУЛЬТАТЫ И ОБСУЖДЕНИЕ}

Природный клиноптилолит Сокирницкого месторождения Закарпатской области с цезием использовали в качестве имитатора отработанного сорбента. Рентгенофазовый анализ (РФА) образца природного клиноптилолита показал, что в его состав входит две основные фазы клиноптилолита $(\mathrm{Na}, \mathrm{K})_{4} \mathrm{CaAl}_{6} \mathrm{Si}_{30} \mathrm{O}_{72} \cdot 24 \mathrm{H}_{2} \mathrm{O}$ (ASTM № 24-0319) и морденита $\left(\mathrm{Na}_{2} \mathrm{Ca}_{2} \mathrm{~K}_{2}\right)_{4} \mathrm{Al}_{8} \mathrm{Si}_{40} \mathrm{O}_{96} \cdot 28 \mathrm{H}_{2} \mathrm{O}$ (RRUFF R070524), a также наблюдаются примеси фаз $\mathrm{SiO}_{2}, \mathrm{Fe}_{2} \mathrm{O}_{3}$ и $\mathrm{TiO}_{2}$. (рис. 1). 
Для насыщения клиноптилолита цезием использовали 0,5 М раствор хлорида цезия. Известно, что степень измельчения клиноптилолита значительно влияет на его сорбционные процессы. Увеличение размера гранул клиноптилолита ведет к резкому снижению сорбционных свойств по отношению к цезию, несмотря на высокую селективность к цезию. Поэтому клиноптилолит предварительно измельчали в ступке и просеивали через сито с размером 100 мкм. Далее, для осуществления насыщения, измельченный клиноптилолит смешивали с водным раствором хлорида цезия и выдерживали в течение недели при комнатной температуре. Ранее было показано, что насыщение природного цеолита для ${ }^{137} \mathrm{Cs}$ достигает максимальной величины при рН равном 10 [9]. Для повышения рН раствора хлорида цезия до 10 добавляли $\mathrm{NaOH.} \mathrm{Насыщенный} \mathrm{цезием}$ клиноптилолит после извлечения из раствора сушили при температуре $110{ }^{\circ} \mathrm{C}$ в течение 24 часов. Химический состав клиноптилолита после насыщения цезием определяли методом лазерной масс-спектроскопии на установке ЭМАЛ-2. Как видно из таблицы 1, содержание цезия в клиноптилолите составляет 12 вес.\% и находится в области значений насыщения клиноптилолита цезием 3,32 - 39,87 вес.\% [4]. Приведенный состав остальных компонентов свидетельствуют о том, что они принадлежат в основном клиноптилолиту и его примесям, что подтверждается данными РФА (рис. 2). Представленные результаты РФА клиноптилолита с цезием показывают, что фазовый состав не изменился, кроме появления фазы хлорида цезия (ASTM № 050607), расположение дифракционных максимумов которого практически совпадает с рефлексами отражений клиноптилолита.

Таблица 1

Химический состав клиноптилолита с цезием

\begin{tabular}{|c|c|c|c|c|c|c|c|c|c|c|}
\hline Состав & $\mathrm{Na}_{2} \mathrm{O}$ & $\mathrm{MgO}$ & $\mathrm{Al}_{2} \mathrm{O}_{3}$ & $\mathrm{SiO}_{2}$ & $\mathrm{~K}_{2} \mathrm{O}$ & $\mathrm{CaO}$ & $\mathrm{TiO}_{2}$ & $\mathrm{Fe}_{2} \mathrm{O}_{3}$ & $\mathrm{H}_{2} \mathrm{O}$ & $\mathrm{CsCl}$ \\
\hline \% вес. & 0,23 & 0,77 & 9,54 & 57,1 & 2,45 & 2,2 & 0,2 & 2,1 & 10,0 & 15,1 \\
\hline
\end{tabular}

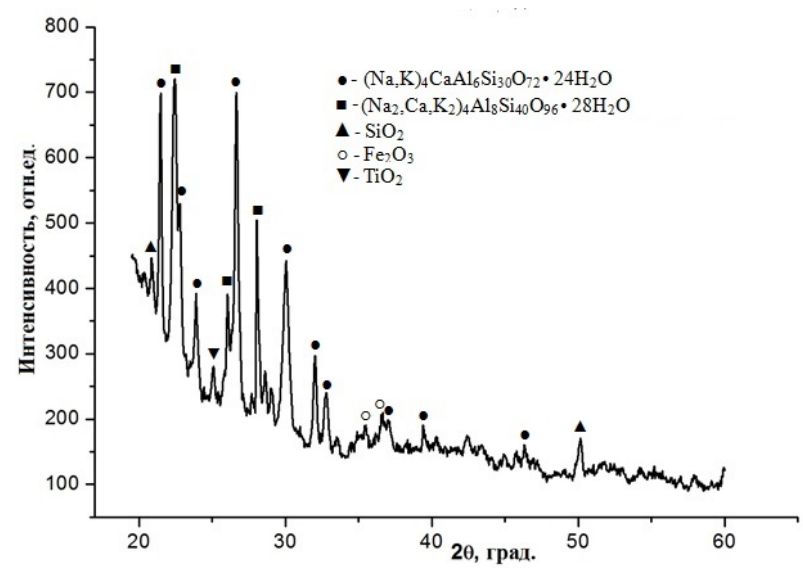

Рис. 1. РФА природного клиноптилолита

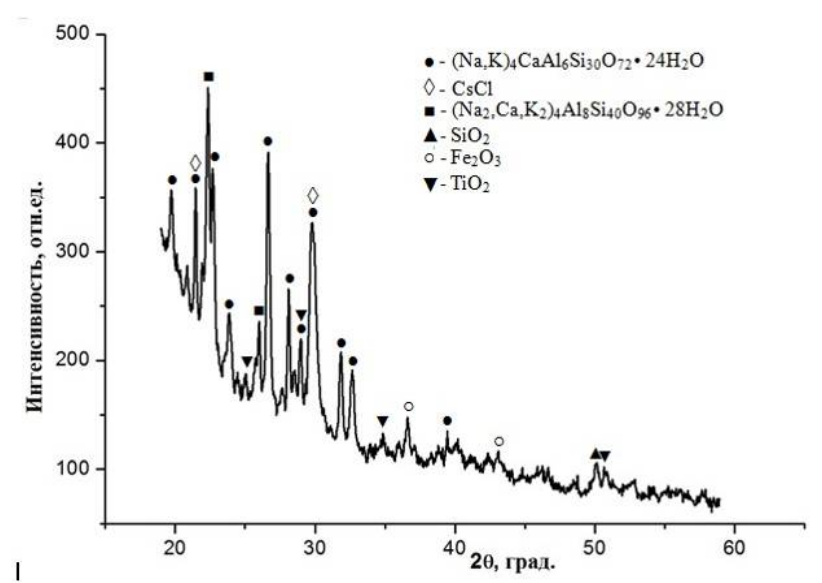

Рис. 2. РФА клиноптилолита с $\mathrm{CsCl}$

На рис. 3 представлены ДТА/ТГ кривые образца клиноптилолита в интервале температур 20-1000 ${ }^{\circ} \mathrm{C}$. Вначале на кривой ТГ до температуры $650{ }^{\circ} \mathrm{C}$ наблюдается монотонное уменьшение массы образца, а затем при повышении температуры масса практически не изменяется. Положение эндотермического пика (от 25 до $300{ }^{\circ} \mathrm{C}$ ) на кривой ДТА соответствует потере воды. В интервале температур $300-1000{ }^{\circ} \mathrm{C}$ эндотермических и экзотермических пиков на кривой ДТА не наблюдается.

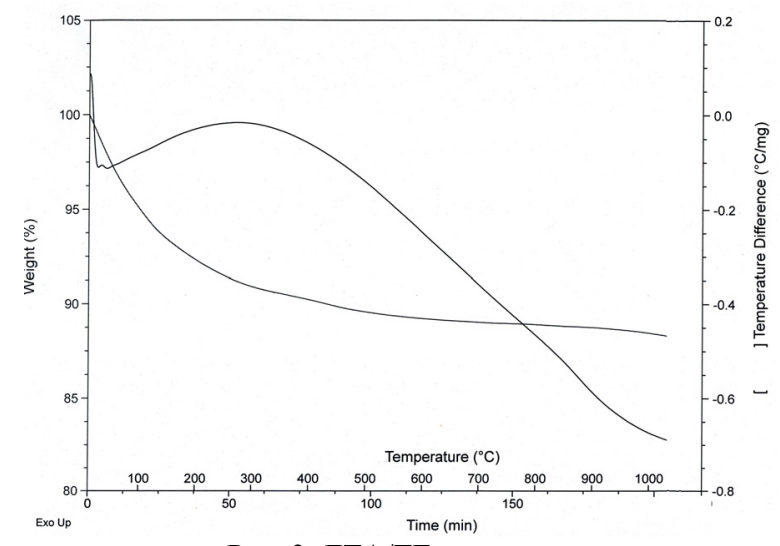

Рис. 3. ДТА/ТГ клиноптилолита

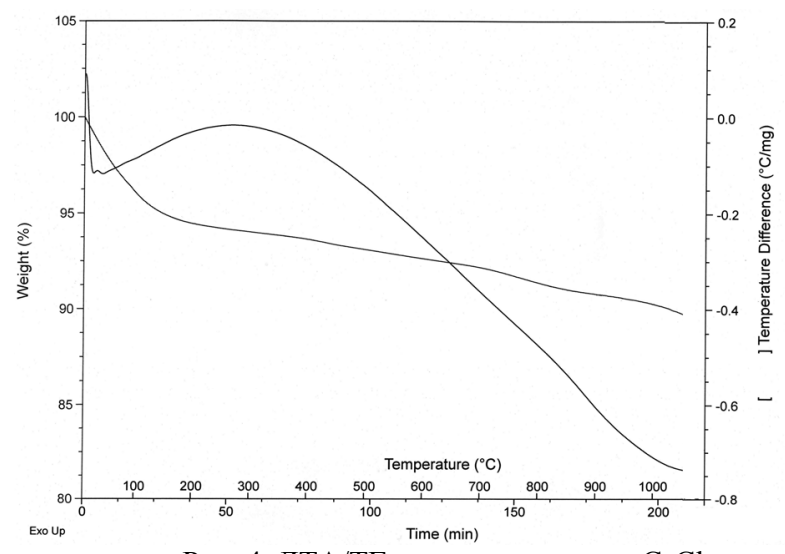

Рис. 4. ДТА/ТГ клиноптилолита с $\mathrm{CsCl}$ 
Сравнение ДТА/ТГ кривых клиноптилолита с цезием (рис. 4) и без него (рис. 3) показало более медленную потерю массы клиноптилолита без цезия. Особенно это касается интервала температур $648-863{ }^{\circ} \mathrm{C}$, который отвечает температурному интервалу полного испарения хлорида цезия (рис. 5).

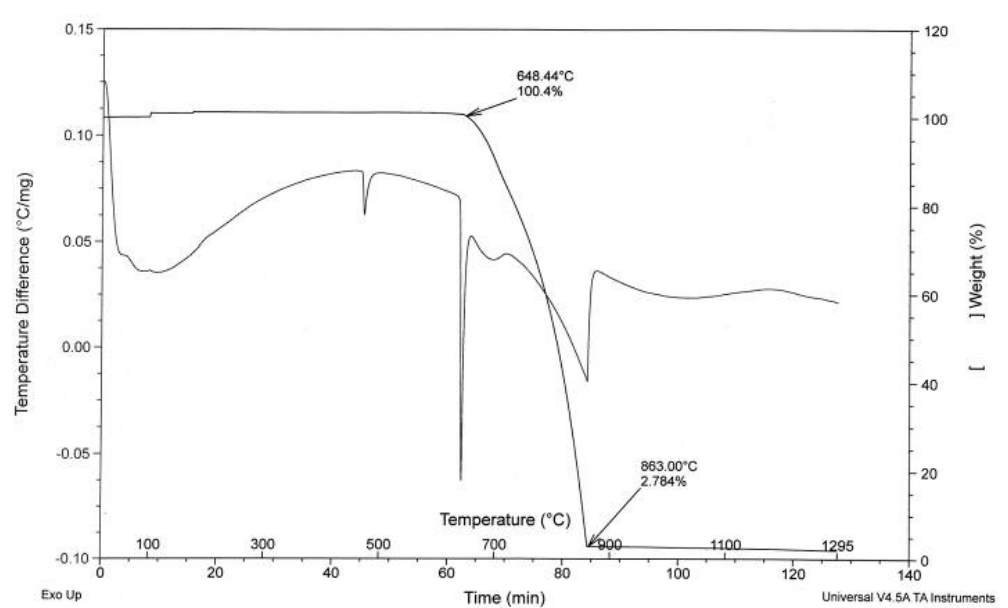

Рис. 5. ДТА/ТГ анализ $\mathrm{CsCl}$

Большая потеря массы образца клиноптилолита с цезием в этом интервале температур вызвана, повидимому, выходом цезия из каналов и полостей структуры клиноптилолита. Перед введением клиноптилолита с цезием в КМФ матрицу было проведено измельчения в планетарной мельнице в течение 4 часов при 300 об./мин. Рассмотрение дифрактограммы измельченного клиноптилолита с цезием показало наличие тенденции к уменьшению интенсивности и количества линий морденита, вследствие того, что он испытывает более значительные разрушения во время измельчения (рис. 6). Известно, что прочность морденита меньше по сравнению с прочностью клиноптилолита.

Для получения калий магний фосфатной матрицы с 25 вес.\% клиноптилолита, насыщенного цезием, раствор дигидрофосфата калия добавляли в перемешанную смесь сухих порошков оксида магния и клиноптилолита с цезием. На рис. 7 представлена блок - схема лабораторного технологического процесса изготовления калий магний фосфатной матрицы с включением в неё клиноптилолита с цезием.

Дифрактограмма образца $\mathrm{KMgPO}_{4} \cdot 6 \mathrm{H}_{2} \mathrm{O}+25$ вес.\% клиноптилолита с Cs представлена на рис. 8 . Из рассмотрения дифрактограммы следует, что полученный материал идентифицируется как калий магний фосфат (ASTM № 35-0812) с присутствием фаз клиноптилолита, морденита, $\mathrm{TiO}_{2}$ и не прореагировавшего $\mathrm{MgO}$.

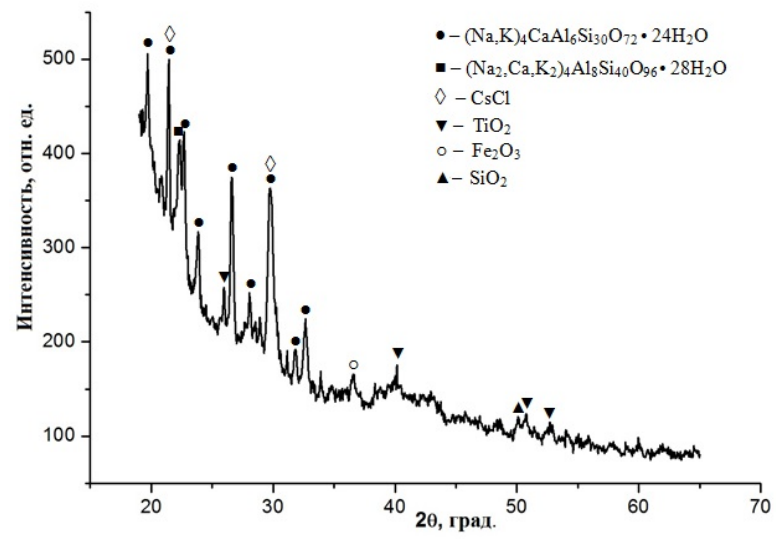

Рис. 6. РФА клиноптилолита с $\mathrm{CsCl}$ после измельчения 4 часа при 300 об./мин

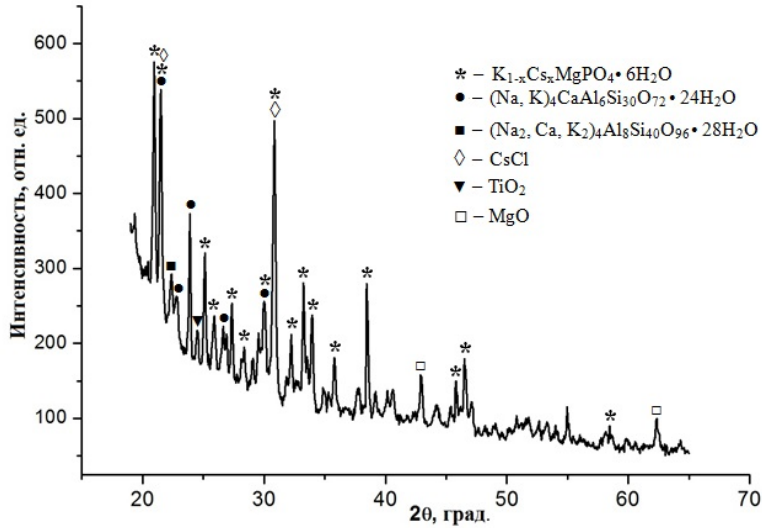

Рис. 8. РФА композиции $\mathrm{KMgPO}_{4} \cdot 6 \mathrm{H}_{2} \mathrm{O}+25$ вес.\% клиноптилолита с $\mathrm{CsCl}$

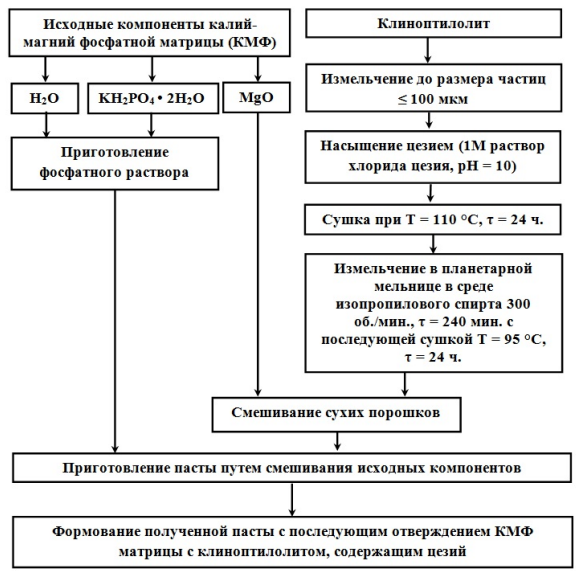

Рис. 7. Блок - схема технологического процесса изготовления калий магний фосфатной матрицы с включением в неё 25 вес.\% клиноптилолита, насыщенного цезия 
Проведенное исследование микроструктуры и элементного состава образцов калий магний фосфатной матрицы +25 вес.\% клиноптилолита с цезием показывает, что в различных участках образца наблюдается неоднородность структуры от волокнистых образований до зерен неправильной формы. Волокнистая структура (рис. 9а) по результатам элементного анализа, в основном, представлена калий магний фосфатной матрицей и незначительным количеством элементов клиноптилолита и цезия ( 3,5 вес.\%) (табл. 2). Длина волокон составляет от 10 мкм до 20 мкм, сечение волокон 3 мкм. В свою очередь зеренная структура (рис. 9б) состоит из элементов как калий магний фосфата, так и клиноптилолита и содержит большее количество цезия ( 13 вес.\%) (табл. 3). Это означает, что вероятно, часть цезия вошла в структуру калий магний фосфата, а другая часть осталась в клиноптилолите, который внедрен в фосфатную матрицу.
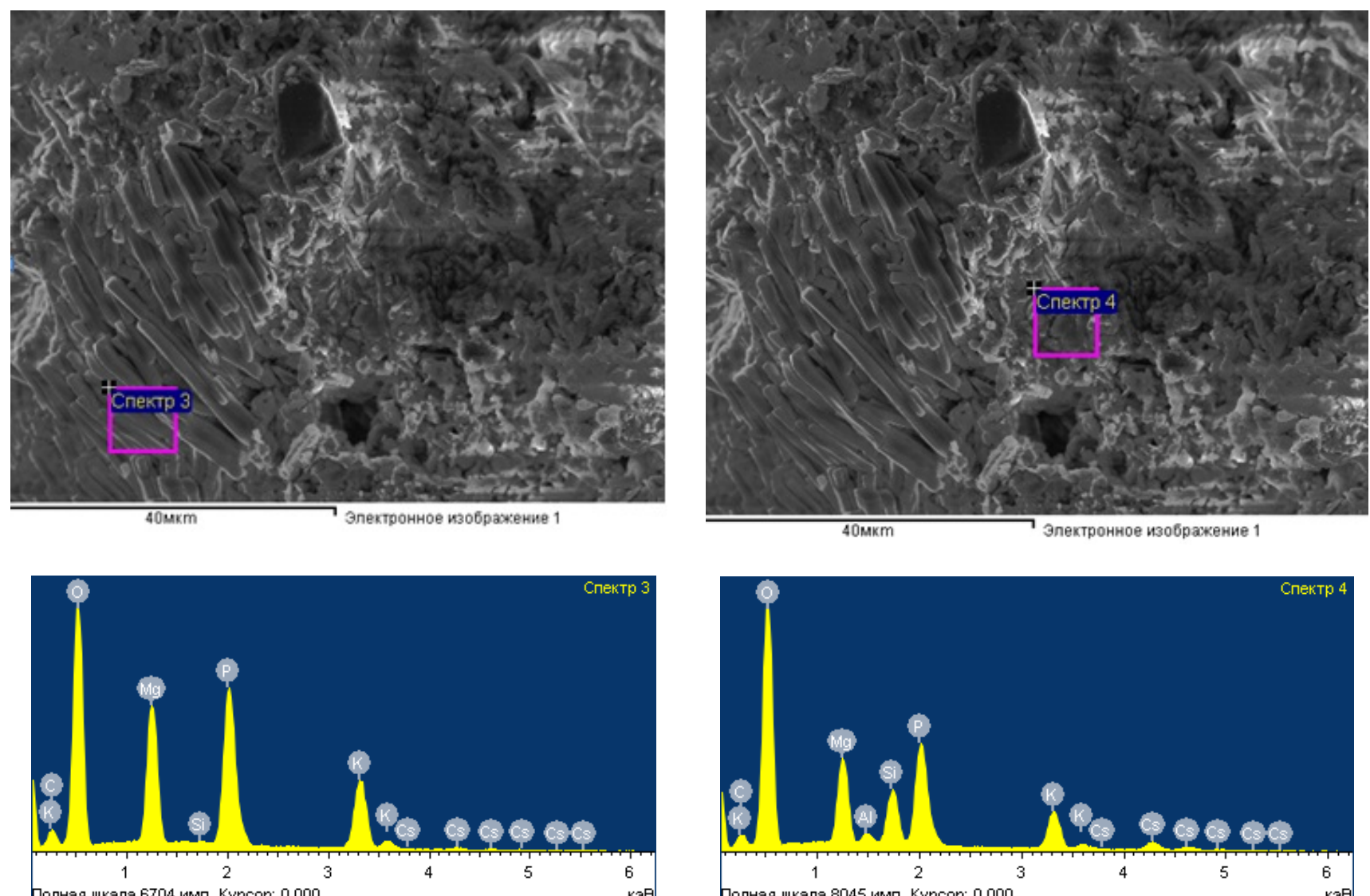

a

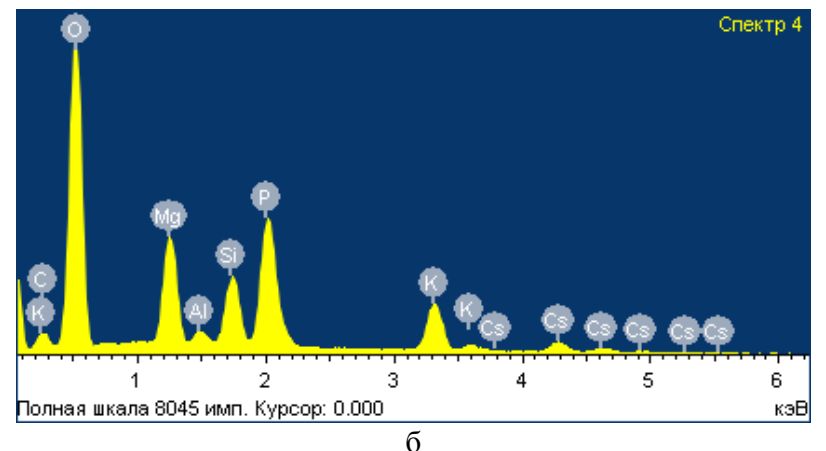

Рис. 9. СЭМ KMgPO 4 -6 $\mathrm{H}_{2} \mathrm{O}+25$ вес.\% клиноптилолита с $\mathrm{Cs}$

Таблица 2

Элементный состав волокнистой структуры КМФ + 25 вес.\% клиноптилолита с цезием (спектр 3)

\begin{tabular}{|c|c|c|c|c|c|c|c|}
\hline Элемент & $\mathrm{O}$ & $\mathrm{Mg}$ & $\mathrm{Si}$ & $\mathrm{P}$ & $\mathrm{K}$ & $\mathrm{Cs}$ & Итого \\
\hline Вес. \% & 46,99 & 12,24 & 0,39 & 19,44 & 17,63 & 3,31 & 100,00 \\
\hline
\end{tabular}

Таблица 3

Элементный состав зеренной структуры КМФ + 25 вес.\% клиноптилолита с цезием (спектр 4)

\begin{tabular}{|l|c|c|c|c|c|c|c|c|}
\hline Элемент & $\mathrm{O}$ & $\mathrm{Mg}$ & $\mathrm{Al}$ & $\mathrm{Si}$ & $\mathrm{P}$ & $\mathrm{K}$ & $\mathrm{Cs}$ & Итого \\
\hline Вес. \% & 45,91 & 8,80 & 0,96 & 6,58 & 14,46 & 10,67 & 12,62 & 100,00 \\
\hline
\end{tabular}

На рис. 10 представлено СЭМ изображение участка образца КМФ матрица +25 вес.\% клиноптилолита с цезием и карты распределения основных элементов. Хорошо видна область, состоящая из не прореагировавших полностью частиц оксида магния (рис. 9а). Сравнение карт распределения цезия и элементов, входящих в состав КМФ и клиноптилолита, также подтверждает вывод о том, что большая часть цезия находится в каналах клиноптилолита. Остальная часть цезия присутствует в КМФ матрице, что свидетельствует о частичном связывании цезия КМФ матрицей. 


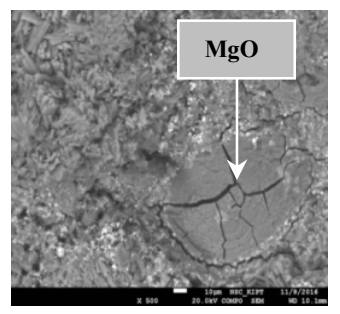

a

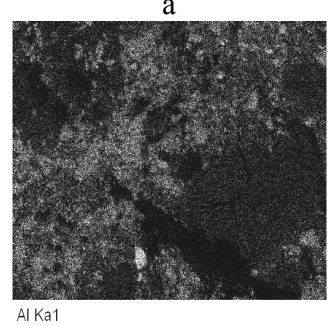

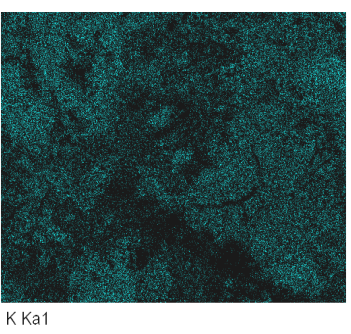

6

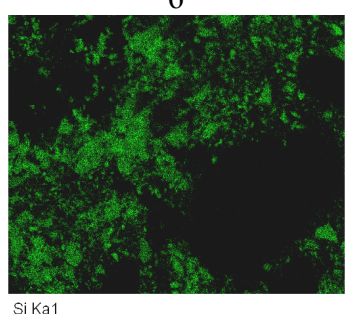

д
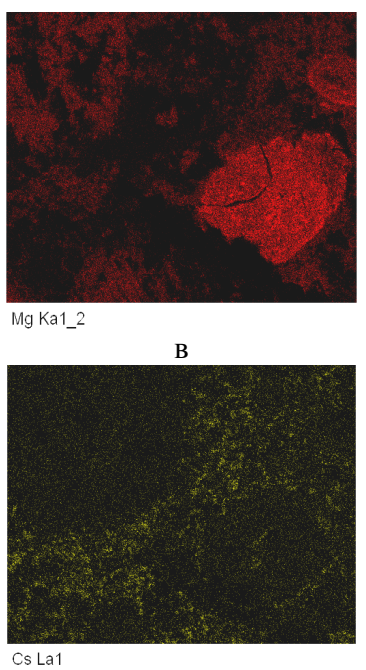

e

Рис. 10. Карты распределения элементов КМФ матрицы + 25 \% клиноптилолита с цезием

Применение различных материалов в качестве матричных или иммобилизационных требует оценки их коррозионных свойств в различных условиях и средах. Для сравнения и оценки этих свойств разработаны и нашли широкое применение различные методы испытаний. Наибольшее признание у специалистов получил тест США MCC-1 (Materials Characterization Center Static Leach Test, USA). Тест на выщелачивание проводили в дистиллированной воде согласно требованиям теста МСС-1, который является статическим тестом для монолитных образцов с известной геометрической поверхностью, при температуре $90{ }^{\circ} \mathrm{C}$ в течение 7 суток. Образцы КМФ матрицы + 25 вес.\% клиноптилолита с цезием помещали в водную среду в тефлоновых контейнерах с плотно закрывающимися крышками. Концентрацию цезия в выщелате определяли методом атомно-абсорбционной спектрометрии с помощью прибора Ace 3000 фирмы Thermo Scientific. Концентрация цезия в исходном образце до выщелачивания была определена расчетным путем на основе данных о содержании хлорида цезия в клиноптилолите. Нормализованная скорость выщелачивания рассчитана, используя следующее уравнение:

$$
v=\frac{A_{n}^{i}}{f_{i} \cdot S A \cdot t_{n}}
$$

где $v$ - скорость выщелачивания отдельных элементов (г/см²·сутки), $A_{n}^{i}$ - концентрація $i$-го элемента (г/л) в выщелате за n-ый интервал времени, $f_{i}$ - массовая концентрация $i$-го элемента в исходном образце (г/г), $S A$ площадь открытой геометрической поверхности образца (см²), $t_{n}-$ продолжительность n-го периода выщелачивания (сутки).

Значение нормализованной скорости выщелачивания цезия из образца КМФ матрица +25 вес.\%

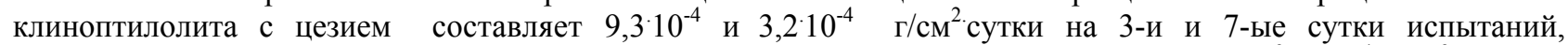
соответственно. Близкие значения нормализованной скорости выщелачивания цезия $\left(\sim 10^{-3}-10^{-4}\right.$ г/см ${ }^{2} \cdot \mathrm{cyтки)}^{2}$ были получены для низко температурной цементно-бентонитовой матрицы с загрузкой 290-350 кг/м³ ионообменной смолы [10]. В работе [4] нормализованная скорость выщелачивания цезия из термообработанных при $750^{\circ} \mathrm{C}$ образцов стекла с различным объемным содержанием клиноптилолита с цезием (1:1 - 1:10) находится в диапазоне $3,37 \cdot 10^{-3}-2,84 \cdot 10^{-7}$ соответственно.

В данной работе проведены исследования по включению 25 вес. \% клиноптилолита с цезием в калий магний фосфатную матрицу, изучен фазовый состав, микроструктура и скорость выщелачивания цезия из полученного материала. Дальнейшая работа будет направлена на увеличение загрузки КМФ матрицы клиноптилолитом с цезием и проведению исследований влияния загрузки на микроструктуру и коррозионную стойкость полученных материалов.

\section{ВЫВОДЫ}

1. Показано, что фазовый состав образцов природного клиноптилолита после насыщения в растворе хлорида цезия и сушки представлен клиноптилолитом, морденитом, примесными фазами $\mathrm{SiO}_{2}, \mathrm{Fe}_{2} \mathrm{O}_{3}$ и $\mathrm{TiO}_{2}$, a также хлоридом цезия. Содержание хлорида цезия составляет 15,1 вес.\%.

2. Интенсивное измельчение природного клиноптилолита с цезием в планетарной мельнице со скоростью 300 об./мин. в течение 4 часов приводит к уменьшению количества морденита.

3. Проведено исследование по включению клиноптилолита, насыщенного цезием, в калий магний фосфатную матрицу. Методом СЭМ показано, что цезий распределился между КМФ матрицей и 
клиноплилолитом, который инкорпорирован в КМФ матрицу.

4. Проведенные коррозионные испытания методом выщелачивания материалов образцов КМФ матрица +25 вес.\% клиноптилолита с цезием. Нормализованная скорость выщелачивания цезия на 7-ые сутки испытаний равна $3,2 \cdot 10^{-4}$ г/см су сутки.

\section{СПИСОК ЛИТЕРАТУРЫ}

1. Rodriguez-Trejo R., Bosch P., Bulbulian S. Combustion treatment of $\mathrm{Co}^{2+}$ and $\mathrm{Cs}^{+}$exchanged zeolites // Journal of Nuclear Materials. - 2006. - Vol. 354. - P. 110-122.

2. Breck D. Tseolitovyye molekulyarnyye sita. // M.: Mir. - 1976. - 139p. (in Russian)

3. A.S. Nikiforov, V.V. Kulinichenko, M.I. Zhikharev. Obezvrezhivaniye zhidkikh radioaktivnykh otkhodov [Neutralization of liquid radioactive waste]. - M: Energoatomizdat, 1985. (in Russian)

4. Juoi J.M., Ojovan M.I., Lee W.E. Microstructure and leaching durability of glass composite waste forms for spent clinoptilolite immobilization // Journal of nuclear materials. - 2008. - Vol. 372. - P. 358-366.

5. Arun S. Wagh. Chemically Bonded Phosphate Ceramics / Twenty-First Century Materials with Diverse Applications, Second Edition, Elsevier, 2016. - 400 p.

6. Vinokurov S.E., Kulyako Y.M., Slyuntchev O.M., Rovny S.I., Myasoedov B.F. Low-temperature immobilization of actinides and other components of high-level waste in magnesium potassium phosphate matrices // Journal of Nuclear Materials. -2009. - Vol. 385. - No. 1. - P. 189-192.

7. Singh D., Mandalika V.R., Parulekar S.J., Wagh A.S. Magnesium potassium phosphate ceramic for ${ }^{99}$ Tc immobilization // Journal of Nuclear Materials. - 2006. - Vol. 348. - P. 272-282.

8. Wagh Arun. S., Sayenko S.Y., Shkuropatenko V.A., Tarasov R.V., Dykiy M.P., Svitlychniy Y.O., Virych V.D., Ulybkina E.A. Cesium immobilization in struvite structures // Journal of Hazardous Materials. - 2016. - Vol. 302. - P. 241-249.

9. Osmanlioglu A.E. Treatment of radioactive liquid waste by sorption on natural zeolite in Turkey // Journal of Hazardous Materials. - 2006. - Vol. B137. - P. 332-335.

10. Plecas I., Pavlovic R., Pavlovic S. Leaching behavior of ${ }^{60} \mathrm{Co}$ and ${ }^{137} \mathrm{Cs}$ from spent ion exchange resins in cement-bentonite clay matrix // Journal of Nuclear Materials. - 2004. - Vol. 327. - Issues 2-3. - P. 171-174. 